
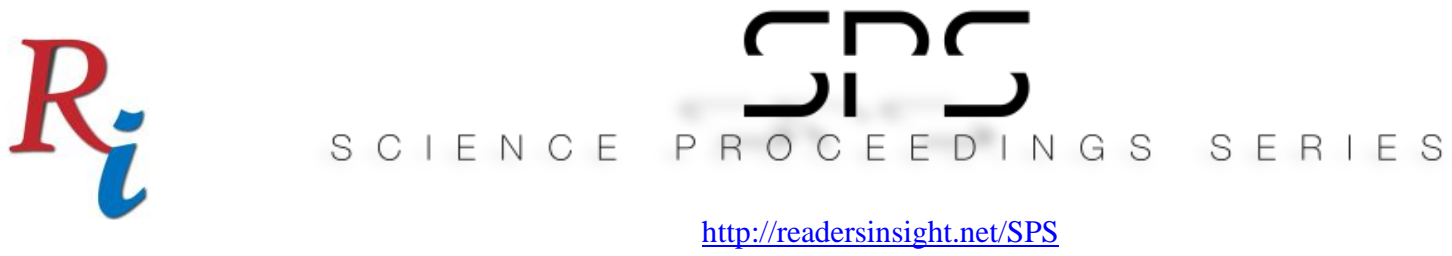

\title{
Concentrated AcId: A Pre-Requisite to ENHANCED METAL DISSOLUTION?
}

\author{
Kasimu Abubakar* \\ Departement of Chemistry \\ Malaysia/Nigeria \\ abubakar.kasimu@graduate.utm.my \\ Azli Sulaiman \\ Departement of Chemistry \\ Universiti Teknologi Malaysia \\ Malaysia \\ azli@kimia.fs.utm.my \\ Jamilu Usman \\ Departement of Chemistry \\ Sokoto State University \\ Nigeria \\ jamiluusman2020@gmail.com
}

aUniversiti Teknologi Malaysia bSokoto State University

*Corrosponding author's Email: abubakar.kasimu@graduate.utm.my

Peer-review under responsibility of 4th Asia International Multidisciplinary Conference 2020 Scientific Committee http://connectingasia.org/scientific-committee/

(C) 2020 Published by Readers Insight Publisher, lat 306 Savoy Residencia, Block 3 F11/1,44000 Islamabad. Pakistan,

editor@ readersinsight.net

This is an open access article under the CC BY-NC-ND license (http://creativecommons.org/licenses/by-nc-nd/4.0/). 

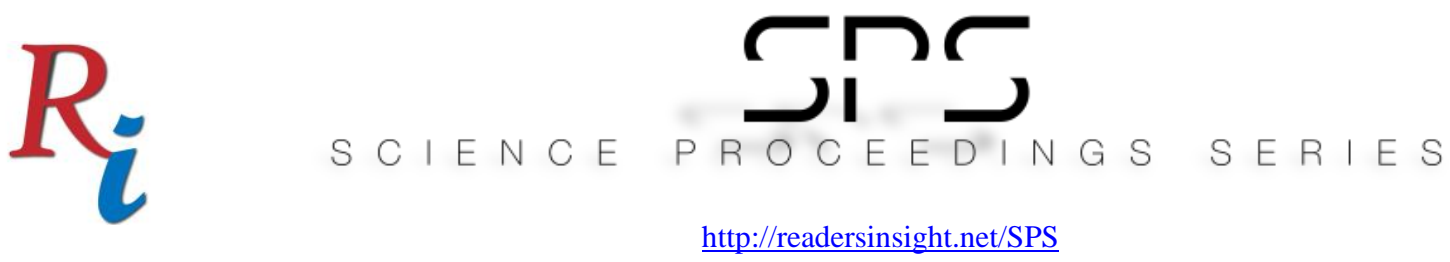

\section{A b s tra c t}

Technological advancement over the past decade has dramatically changed with new players such as China taking lead in information-technology and telecommunication market across the world. This development has seen surge in manufacturing industry output and consequently raw materials consumed by the sector. The environmental impact is however evident due to human interference with nature. E-waste is the fastest growing waste stream posing serious risk to fauna and flora due to numerous associated pollutants. In recycling industry, hydrometallurgy is widely adopted to recover metals from e-waste. Despite growing concern over secondary pollution associated with disposal, concentrated aqua regia is widely used to extract metals from e-waste. An ultrasonic bath enhanced dilute-acid leaching method was developed to recover copper and lead from waste mobile phone PCB. Repeatability and reproducibility showed $5.3 \%$ and $5.0 \%$ with respect to $\mathrm{Cu}$ while $9.8 \%$ and $6.3 \%$ RSD were recorded for lead. LOD and LOQ of $0.02 \mu \mathrm{g} / \mathrm{g}$ and $0.064 \mu \mathrm{g} / \mathrm{g}(\mathrm{Cu})$ and $0.082 \mu \mathrm{g} / \mathrm{g}$ and 0.312 $\mu \mathrm{g} / \mathrm{g}(\mathrm{Pb})$ revealed that the method is suitable for dissolution of target metals from PCBs. Copper concentration of $332.98 \mathrm{mg} / \mathrm{g}$ recorded inferred that dilute aqua regia as much as concentrated has promising metal extraction power and thus could replace concentrated acids.

\section{Research High I ight s}

Electrical and electronic equipment (EEE), from household appliances to I.T and telecommunication gadgets have over the years become indispensable in our lives. Short life cycle and technological innovation render EEE redundant, leading to the unprecedented rise in the generation of e-waste [1\&2]. Millions of tons of e-waste are generated worldwide with an important increase expected annually [3].

Large portions of pollutant harbored e-waste produced in the developed world end up in informal recycling plants and landfills with adverse consequences for the environment [4]. A fraction of it, however, is processed via the take-back system to recover metals using various recycling routes [5-7] thereby, mitigating hazardous substances disposal.

Chemical approach achieves excellent metal recovery within a relatively short period of time [8] but there is increasing concern over the resulting secondary pollution [9]. Present research used diluted mineral acids to extract metals from waste mobile phone printed circuit board.

\section{Research Objectives}

To extract metals from obsolete mobile phone printed circuit board using dilute mineral acids and determine the concentration of copper and lead from the leach liquor using flame atomic absorption spectroscopy.

Copyright $(\odot) 2020$ Authors. This is an open access article distributed under the Creative Commons Attribution License, which permits unrestricted use, distribution, and reproduction in any medium, provided the original work is properly cited. 

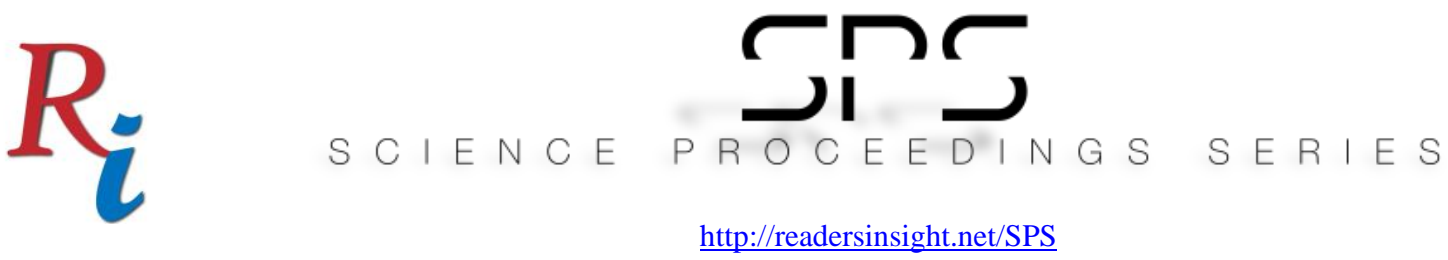

Finding the most suitable solvent under the adopted conditions and contrasting the reported findings with established work using concentrated acid and eventually determining the role of acid concentration in the leaching of metals from e-waste.

This research will help minimize the adverse effects on the ecosystem caused by the concentrated acid effluent released from e-waste treatment.

\section{Methodology}

Experimental work was carried out using waste cell phone PCB shredded and milled into fine particles following dismantling of electronic components mounted on the PCBs. $50 \mathrm{ml}$ of $2 \mathrm{M}$ of dilute mineral acid viz. $\mathrm{HCl}, \mathrm{H}_{2} \mathrm{SO}_{4}, \mathrm{HNO}_{3}, \mathrm{HCl}: \mathrm{HNO}_{3}, \mathrm{H}_{2} \mathrm{SO}_{4}: \mathrm{HNO}_{3}$ and $\mathrm{H}_{2} \mathrm{O}_{2}: \mathrm{HNO}_{3}$ were measured while maintaining 1:1 (volume ratio) where two different acids were involved, and $0.3 \mathrm{~g}$ of dried ground sample were added into a volumetric flask.

The resulting mixture was then taken to ultrasonic bath to provide agitation and heating at $70^{\circ} \mathrm{C}$ temperature for a reaction time of $45 \mathrm{~min}$. The leachates were then subjected to flame atomic absorption spectroscopy to determine copper $(\mathrm{Cu})$ and lead $(\mathrm{Pb})$.

\section{Results}

The result showed $\left(\mathrm{HCl}: \mathrm{HNO}_{3}\right)$ had better leaching strength with concentration of $333 \mathrm{mg} / \mathrm{g}$ $\mathrm{Cu}$ while $\mathrm{HCl}$ had the lowest concentration $(28 \mathrm{mg} / \mathrm{g})$ and a similar trend were observed in $\mathrm{Pb}$. Overall, low concentration recorded in $\mathrm{Pb}$ leaching may be due to the adoption of high temperature, thus, affecting extraction of the relatively volatile metal.

Notably, the dissolution capacity shown by Aqua regia is only slightly above that shown by nitric acid alone. This can be due to the excellent nature of dissolution of metals by the oxidant which has been reported to give near complete leaching of $\mathrm{Cu}$. Aqua regia itself exhibits remarkable leaching strength mainly due to oxidizing agent $\left(\mathrm{HNO}_{3}\right)$ it contains which is capable of enhancing metals dissolution from e-waste.

\section{Findings}

The reagents in combine form viz. $\mathrm{HCl}$ : $\mathrm{HNO}_{3}, \mathrm{H}_{2} \mathrm{SO}_{4}: \mathrm{HNO}_{3}, \mathrm{HNO}_{3}: \mathrm{H}_{2} \mathrm{O}_{2}$ and nitric acid demonstrated impressive metal extraction. The highest $\mathrm{Cu}$ concentraton of about $333 \mathrm{mg} / \mathrm{g}$ leached is relatively close to $\mathrm{Cu}$ concentration of $395 \mathrm{mg} / \mathrm{g}$ reported when concentrated aqua regia was used to recover metals from broken cell phone PCBs [7]. This study thus concluded that concentration of acid may not have a major impact on the leaching of metals from waste 

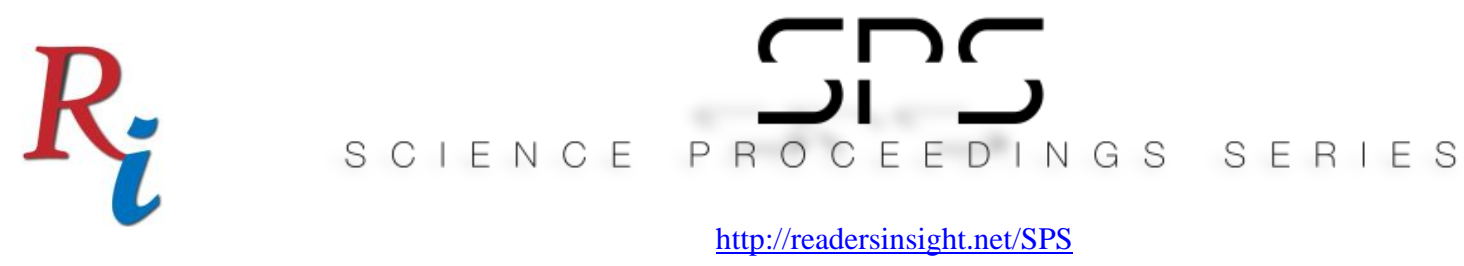

PCBs. Consequently, dilute acid may replace the use of concentrated ones in metal dissolution resulting in decreased environmental impact and reduced disposal cost.

\section{REFERENCES}

[1] M Khurrum S B, Adnan O, Xiaozhe Y. Electronic Waste: A Growing Concern in Today's Environment. Economics Research International. 2011 Jun 15;2011.

[2] Chen Y, Chen M, Li Y, Wang B, Chen S, Xu Z. Impact of technological innovation and regulation development on e-waste toxicity: a case study of waste mobile phones. Scientific reports. 2018 May 8;8(1):1-9.

[3] Li J, Jiang Y, Xu Z. Eddy current separation technology for recycling printed circuit boards from crushed cell phones. Journal of Cleaner Production. 2017 Jan 10;141:131623.

[4] Annamalai J. Occupational health hazards related to informal recycling of E-waste in India: An overview. Indian journal of occupational and environmental medicine. 2015 Jan;19(1):61.

[5] Jadhav U, Su C, Hocheng H. Leaching of metals from printed circuit board powder by an Aspergillus niger culture supernatant and hydrogen peroxide. RSC advances. 2016;6(49):43442-52.

[6] Mizero B, Musongo T, Rene ER, Battes F, Lens PN. Optimization of process parameters for the chemical leaching of base metals from telecom and desktop printed circuit boards. Process Safety and Environmental Protection. 2018 Nov 1;120:14-23.

[7] Hageluken C, Art S. Recycling of e-scrap in a global environment: opportunities and challenges. Tackling e-waste towards efficient management techniques, TERI Press, New Delhi. 2007:87-104.

[8] Holgersson S, Steenari BM, Björkman M, Cullbrand K. Analysis of the metal content of small-size Waste Electric and Electronic Equipment (WEEE) printed circuit boardsPart 1: Internet routers, mobile phones and smartphones. Resources, conservation and recycling. 2018 Jun 1;133:300-8.

[9] Akcil A, Erust C, Gahan CS, Ozgun M, Sahin M, Tuncuk A. Precious metal recovery from waste printed circuit boards using cyanide and non-cyanide lixiviants-a review. Waste management. 2015 Nov 1;45:258-71. 